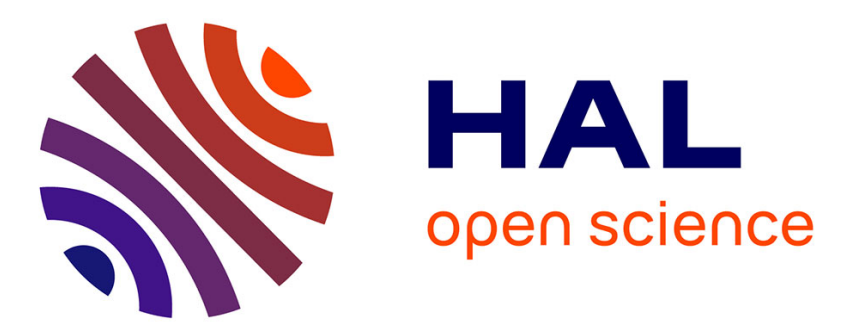

\title{
T-16 Modeling and Experimental Identification for Muscular force Estimation Based on Evoked EMG in FES
}

Mitsuhiro Hayashibe, Qin Zhang, David Guiraud, Charles Fattal, Philippe Fraisse

\section{To cite this version:}

Mitsuhiro Hayashibe, Qin Zhang, David Guiraud, Charles Fattal, Philippe Fraisse. T-16 Modeling and Experimental Identification for Muscular force Estimation Based on Evoked EMG in FES. Journal of Biomechanics, 2010, 43 (Sup. 1), pp.S66. 10.1016/S0021-9290(10)70146-9 . lirmm-00530135

\section{HAL Id: lirmm-00530135 \\ https://hal-lirmm.ccsd.cnrs.fr/lirmm-00530135}

Submitted on 27 Oct 2010

HAL is a multi-disciplinary open access archive for the deposit and dissemination of scientific research documents, whether they are published or not. The documents may come from teaching and research institutions in France or abroad, or from public or private research centers.
L'archive ouverte pluridisciplinaire HAL, est destinée au dépôt et à la diffusion de documents scientifiques de niveau recherche, publiés ou non, émanant des établissements d'enseignement et de recherche français ou étrangers, des laboratoires publics ou privés. 


\title{
MODELING AND EXPERIMENTAL IDENTIFICATION FOR MUSCULAR FORCE ESTIMATION BASED ON EVOKED EMG IN FES
}

\author{
M. Hayashibe, Q. Zhang, D. Guiraud, C. Fattal, P. Fraisse \\ LIRMM-INRIA, DEMAR Project, \\ 161 Rue Ada - 34392 Montpellier Cedex 5, France \\ Propara Rehabilitation Center, \\ 263 rue du Caducee, Parc Euromedecine - 34195 Montpellier Cedex 5, France
}

\begin{abstract}
(400 words)
Functional Electrical Stimulation (FES) has been used to restore motor function or produce movements in Spinal Cord Injured (SCI) patients. However, muscle fatigue is an unavoidable problem when electrical stimulation is applied to paralyzed muscles. The detection and compensation of muscular force decreased by muscle fatigue is essential to avoid movement failure and achieve the desired trajectory. In addition, there is no sensory feedback for SCI patients to monitor their muscular force and fatigue condition. An adequate implantable force sensor is not yet available to be used for FES control. Therefore, it's essential to monitor muscle state and assess the generated force to compensate the fatigue and achieve more precise FES control considering the muscle state. It's also important to cease the stimulation depending on muscle fatigue to prevent serious muscle damage.
\end{abstract}

In the previous researches, one reported solution is to use stimulus evoked EMG (eEMG) signal for prediction of the varied muscle force. It is important to predict generated force when FES is applied along with muscle fatigue. In this work, we aim to predict ankle plantar-flexion torque using eEMG during different muscle fatigue level. Five spinal cord injured patients were recruited for this study. An intermittent fatigue protocol was delivered to triceps surae muscle to induce muscle fatigue. A hammerstein model was used to capture the muscle contraction dynamics to represent eEMG-torque relationship. The prediction of ankle torque was based on measured eEMG and past measured or past predicted torque. The latter approach makes it possible to use only eEMG for muscle force prediction when force measurement is not available in daily use. Some previous researches suggested the usage of eEMG information to detect and predict muscle force during fatigue assuming a fixed relationship between eEMG and generated force. However, we found that the prediction became less precise with the increase of muscle fatigue when fixed parameter model was used. Therefore, we carried out the 
International Conference on Orthopaedic Surgery, Biomechanics and Clinical Applications 6-9 June 2010 Orthopaedic Research and Learning Centre Brunel University, West London UK

torque prediction with adaptive parameters using the latest measurement. The prediction of adapted model was improved with $16.7 \%-50.8 \%$ comparing to the fixed model.

This presentation especially focuses on the modelling methodology and experimental identification algorithms to track the relationship variation between evoked EMG and torque induced by electrical stimulation according to the muscle fatigue. For the future, we aim at on-line estimation of varying torque due to muscle property change based on evoked EMG signals to be applied for new FES control strategy. 